\title{
A KőZETJÖVESZTŐ BONTÓFOGAK OPTIMÁLIS MÉRETEZÉSE
}

\section{DIGGING TOOLS OPTIMAL DIMENSIONING}

\author{
Kovács József ${ }^{1}$, András József ${ }^{2}$, András Endre $^{3}$ \\ Petrozsényi Egyetem, 332006, Románia, Petrozsény, str.Universităţii,20 \\ ${ }^{1}$ kovacsi@mail.com \\ 2 iosif.andras@gmail.com \\ 3 andrei.andras@gmail.com.
}

\begin{abstract}
The paper deals with the digging tools mounted on the buckets of bucket wheel excavators, so called teeth, namely with their shape and strength optimization, taking into account different operating situations, including extreme ones. The excavation process has a complex character, which requires a multi-criterion optimization approach. The experience gained by the authors and the literature findings have demonstrated that this requirement is possible to be fulfilled only when in theoretical mathematical assumptions we use data gathered from rig and in-situ measurements. In this respect, we determined the constructive, shape and strength parameters of teeth in order to obtain maximal excavation productivity and increased reliability.
\end{abstract}

Keywords: Bucket wheel excavator, tooth, optimization, dimensioning

\section{Összefoglalás}

A dolgozat a bányászatban alkalmazott kotrógépek bontófogainak mértani paramétereivel, ezek optimalizálásával foglalkozik, figyelembe véve az üzemelés közben létrejövő helyzeteket, beleértve a szélsőségeseket is. A jövesztési folyamat egy komplex jelenség, amely egy többcél-függvényü optimalizálási megközelítést igényel. A szerzők által nyert tapasztalat, valamint a szakirodalom jelzései azt bizonyítják, hogy csak akkor lehet ezt az igényt kielégíteni, ha a kifejlesztett elméletben található matematikai összefüggésekbe a gyakorlatból vett, labor és in situ mérések alapján meghatározott adatokat használunk fel. Ezt az irányt követve sikerült meghatározni a bontófog paramétereinek értékeit úgy, hogy az maximális hatékonysággal müködjön, és a megbízhatósága is magas legyen.

Kulcsszavak: kotrógép, bontófog, optimalizálás, jövesztés

\section{Bevezető}

Mind az elméleti, mind a gyakorlatban végzett kutatások azt bizonyítják, hogy a marótárcsás kotrógépek esetében a bontófogak mértani paraméterei lényegesen befolyásolják a jövesztést és a gép müködését, föleg ami a marótárcsát, a merítékeket és a bontófogakat illeti, úgy technológiai, mint energetikai szempontból.

A mértani paraméterek elsősorban magára a bontófogra vonatkoznak, mint az egész konstrukció elemei, utána a merítékre szerelt bontófog geometriai paraméterei és végül azok a mértani paraméterek, amelyek a bontófogak eloszlásából származnak. 
A jelen dolgozatban elvégzett optimalizálás egyelőre a bontófogakra mint önálló elemekre vonatkozik, figyelembe véve a bontófogak racionális vágóélre ültetését különböző merítékek esetében.

A feladat megoldását az nehezíti, hogy a jövesztéssel kapcsolatos, véletlenszerü és ellentétes értelmü jelenségeket nagyon sok paraméter határozza meg, ezért, gyakorlatilag nem lehet olyan pontos matematikai összefüggéseket felírni, amelyek precízen fedjék a valóságot.

A valóság jobban megközelíthető, ha a jövesztési labor- és in situ kísérletek során mért adatokat használjuk fel, mind az öszsze-függések, mind a paraméterek értékeinek viszonylatában.

Amint ismert, a bontófogak formája és mértani paraméterei lényegesen befolyásolják a fajlagos energiafogyasztást, de a bontófogak élettartamát is, figyelembe véve a bontófog alapanyagának fizikai és mechanikai tulajdonságait.

Ezenkívül figyelembe kell venni a bontófogak kopását is, e tekintetben lényeges olyan bontófogformából kiindulni, amely minél hosszabb ideig megőrzi eredeti mértani paramétereit.

A bontófogak megfelelő minősége nemcsak a kotrógép alacsony energiafogyasztású üzemeléséhez vezet, hanem a fogfogyasztás is csökken, ami a hatékonyság növelését és a költségek csökkenését vonja maga után.

\section{A bontófog mértani paraméterei}

A bontófogak mértani paramétereit ezek formája és típusa határozza meg.

Ezek függnek a jövesztett anyag minőségétől és a forgácsolhatósági jellemzőitől, a meríték és a marótárcsa konstrukciós paramétereitől, a kotrógép müködési adataitól, a bontófog szilárdságtani tulajdonságaitól és a kopás intenzitásától.

A gyakorlatban két alaptípusú bontófogat használnak, éspedig a hasáb alakú és a körkúp alakú bontófogat. A körkúp alakú típust inkább a rakodógépeknél és az egymerítékes kotróknál használják, míg a hasáb alakút többek között a marótárcsás kotrógépeknél talált alkalmazásra az előnyösebb jövesztési jellemzői matt.

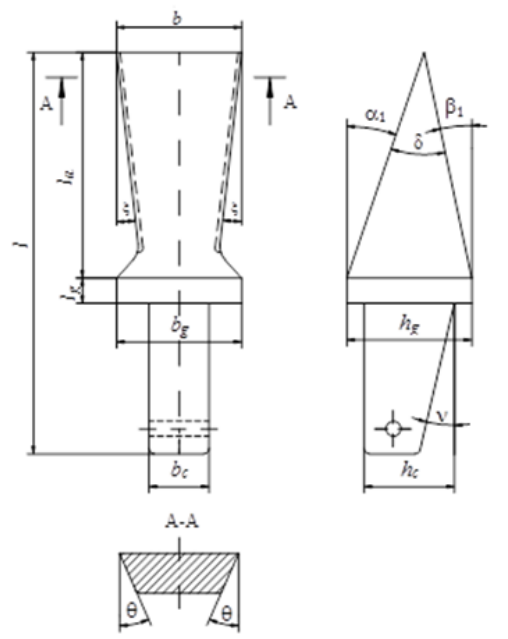

1. ábra. Az önálló bontófog mértani paraméterei

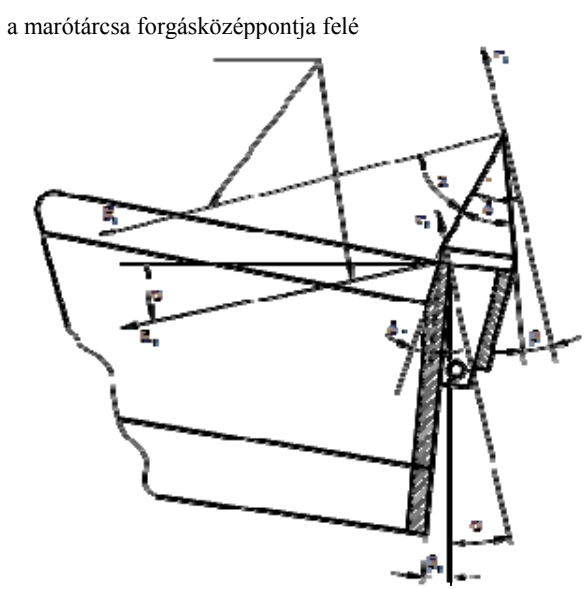

2. ábra. A meriték vágóélére szerelt bontófog mértani paraméterei

$A z$ 1. ábrán az önálló bontófog mértani paraméterei, a 2. ábrán pedig a meríték 
vágóélére szerelt bontófog megfelelő paraméterei vannak feltüntetve.

Amint e két ábrából következik, a főbb paraméterek a következők:

$l$ - a bontófog hossza,

$l_{a}$ - a bontófog aktív hossza,

$b-$ a vágóél szélessége,

$R_{t}$ - a marótárcsa sugara a bontófog éléig,

$R_{c}$ - a marótárcsa sugara a meríték éléig,

$\alpha$ - homlokszög,

$\beta$ - hátszög,

$\gamma$ - vágószög,

$\delta$ - ékszög,

$\theta$ - keresztirányú oldalszög,

$\xi$ - hosszanti oldalszög,

$\varphi-$ a fogélpálya érintőjének a függőlegessel bezárt szöge,

$\alpha_{1}-$ az önálló bontófog homlokszöge,

$\beta_{1}-$ az önálló bontófog hátszöge,

$v_{\mathrm{t}}$ - vágósebesség,

$v_{\mathrm{c}}$ - a merítékél sebessége.

A bontófogat jellemző szögek közötti kapcsolatok a következők:

$\alpha+\gamma=90^{\circ}$

$\gamma=\beta+\delta$

$\delta=90^{\circ}-(\alpha+\beta)$

$\alpha_{1}+\beta_{1}=\delta$

A gyakorlatban az $\alpha$ homlokszög $40 \ldots 60^{\circ}$, a $\beta$ hátszög $5 \ldots 15^{\circ}$, a $\gamma$ vágószög $30 \ldots 50^{\circ}$, a $\delta$ ékszög $25 \ldots 45^{\circ}$, a bontófog hossza $300 \ldots 500 \mathrm{~mm}$, míg a vágóél szélessége $80 \ldots 180 \mathrm{~mm}$. Természetes, hogy az önálló bontófog geometriai paraméterei és a merítékre szerelt bontófog geometriája között pontos összefüggések vannak.

Ezeket szigorúan be kell tartani a rögzítési rendszertől függetlenül, mert ellenkező esetben megváltozik a jövesztett kőzet és a marótárcsa között létrejövő kölcsönhatás, és a kotrógép müködése nem lesz megfelelő.

\section{A bontófogak geometriájának hatása a jövesztésre}

A heterogén anyagok, mint a kőzetek vagy a hasznos ásványi anyagok jövesztése, egyrészt a jövesztett anyag jellemzőitől, másrészt pedig a jövesztőszerszám alakjától és mértani paramétereitől függ.

A természetben elöforduló anyagok közül nagyon sok forgácsolható. Ezeket többek között, kotrógépekkel lehet kitermelni.

A jöveszthető anyag sokféle, nemcsak ami a szerkezetét és fizikai jellemzőit illeti, hanem a jövesztési folyamatban a forgácsképződést és a forgácskitörést is figyelembe véve.

A 3. ábra négyféle anyagtípus jövesztése következtében létrejövő forgácskitörést szemlélteti.

A 3a. ábrán látható a kompakt, de törékeny anyag jövesztése. Itt a forgácsok méretei megközelítőleg egyformák. Ezek, a jövesztés folyamatában elugranak a foghomlokról, s ebből kifolyólag a kopás kisebb, a rányomó erő pozitív, tehát a kőzet ellenáll a bontófog behatolásának a haladási sebesség irányában.

A 3b. ábrán látható a természetesen létrejött repedésekkel rendelkező törékeny anyag jövesztése, ahol a forgácsok különböző méretüek, és sok apró szemcsét tartalmaznak. Ebben az esetben nagy menynyiségü por keletkezik. A jövesztés dinamikus, a kopás nem nagy, és az erők pozitív irányban hatnak.

A 3c. ábrán a rugalmas, jól hajlítható anyagok jövesztése van feltüntetve, amelyek átveszik és elnyelik a befektetett energia egy részét. A forgács, mielőtt repedne, ránehezedik a bontófog homlokára, és emiatt a rányomó erő eredője nagyobb homlokszög esetében, negatív lesz. A homlokfelületen a kopás jelentős, mert ezen csúsznak a forgácsdarabok. Ilyen például a xiloid (fás) lignit jövesztése.

A 3d. ábra a gyenge kohéziós és természetesen szemcsés anyagok (kavics, homok, lösz) jövesztési modelljét szemlélteti, ahol azt lehet kiemelni, hogy a hatóerök nem nagyok, a forgács tulajdonképpen a bontófoghomlokon felcsúszó csomóvá lett anyagmennyiség, amely miatt a rányomó erők eredője szintén negatív, akárcsak az 
elöző esetben. Az ilyen kőzetek általában nagy szilíciumtartalommal rendelkeznek, és így a homlokfelület kopása igen intenzív.

A harmadik és negyedik esetben mondottakat két példával támasztjuk alá, éspedig figyelembe véve a dél-romániai lignittelepekről származó mintákon végzett laboratóriumi jövesztési kísérletek során rögzített

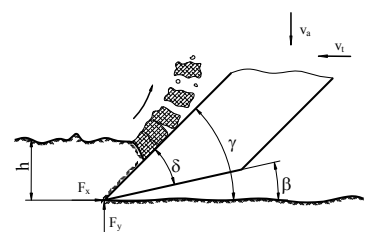

a)

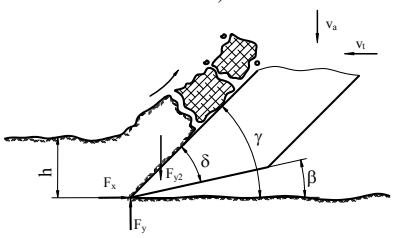

c) és matematikailag feldolgozott adatokat, amelyek a rányomó erő változására vonatkoznak a fogásmélység függvényében, különböző homlokszög értékekre.

A 4. ábrán az I. telepre vonatkozó adatok, az 5. ábrán a $X$. telepre vonatkozó eredmények vannak feltüntetve.

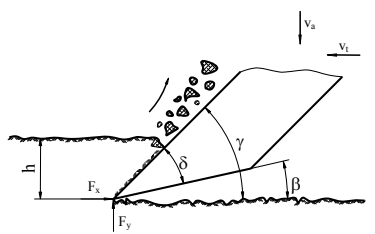

b)

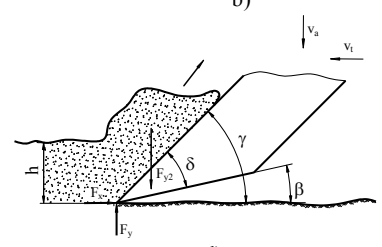

d)

3. ábra. A nem homogén anyagok jövesztési módja

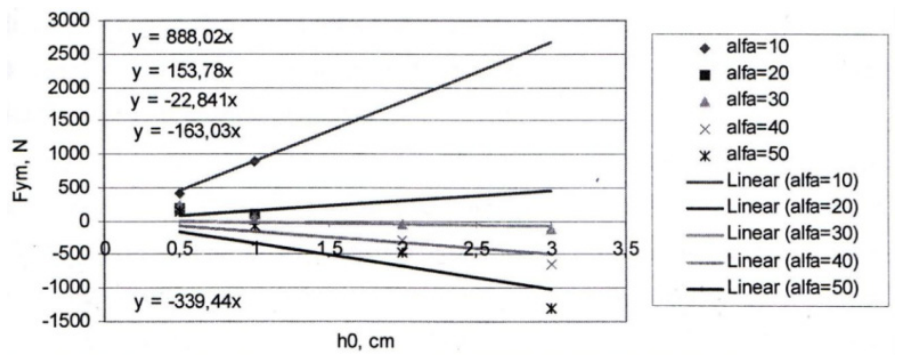

4. ábra $A$ rányomó erő változása a fogásmélység függvényében az I. telep esetében
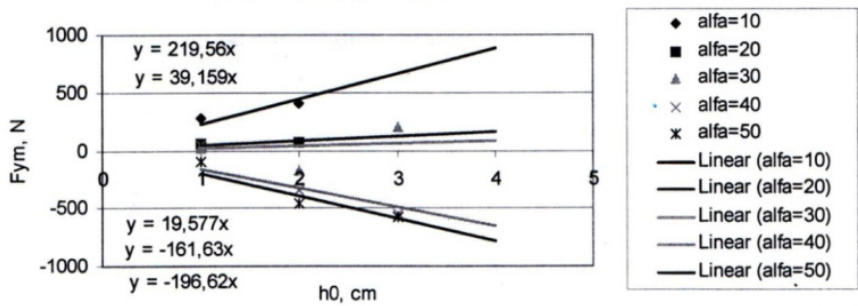

5. ábra. A rányomó erō változása a fogásmélység függvényében az X. telep esetében 
Mindkettőn látható az, hogy a 10, 20 és $30^{\circ}$-os homlokszögü bontófogak esetében az $\mathrm{F}_{\mathrm{y}}$ rányomó erő konvencionálisan pozitív, tehát a lignit ellenáll a behatolásnak, míg 40 és az $50^{\circ}$-os homlokszög esetében az $\mathrm{F}_{\mathrm{y}}$ rányomó erő konvencionálisan negatív, mintha a lignittelep vonzaná a bontófogat.

Ezek az adatok bizonyítják azt, hogy a jövesztés tanulmányozásában milyen nagy szerepet játszik a bontófogak geometriája.

\section{A homlokszög hatása a fogak terhelésére és a jövesztés ener- getikájára}

Mind a hazai, mind a külföldi irodalomból és saját tapasztalatból is ismert, hogy a kőzetek vagy a hasznos ásványok jövesztését lényegesen befolyásolják a bontófogak geometriai paraméterei, főleg ami a vágóés rányomó erőket, a kitörési szöget, valamint a fajlagos energiafogyasztást illeti, amelyek továbbá befolyásolják a fogak, a merítékek és a marótárcsa terhelését, a fogkopást, valamint a jövesztés hatékonyságát általában.

A bontófog geometriai paraméterei közül az egyik legnagyobb szerepet a bontófog $\alpha$ homlokszöge, illetve ennek a kiegészítőszöge, a $\gamma$ vágószög játssza.

A többi élszög, mint a $\beta$ hátszög, a $\theta$ és $\xi$ oldalszögek értéke egy szük intervallumban mozog, és a fölösleges súrlódások elkerülése függvényében állapítható meg. Ha a $\beta$ adott, akkor a $\delta$ ékszög is az $\alpha$-tól függ.

A lignit, a kőszén, a kősó és a különböző meddőkőzet jövesztésére vonatkozó laboratóriumi vagy üzemi körülmények között végzett vizsgálatok rámutattak arra, hogy az $\mathrm{F}_{\mathrm{x}}$ vágóerő és $\mathrm{az} \mathrm{F}_{\mathrm{y}}$ rányomó erő csökken, ha nö az $\alpha$ szög értéke. A szögek közötti összefüggések viszont azt mutatják, hogy ha nő az $\alpha$ homlokszög, akkor megfelelő $\beta$ hátszög esetében ez a $\delta$ ékszög rovására megy, ami a bontófog teherbírásának csökkenését vonja maga után.
Észrevehető, hogy a két megállapítás igaz, de ellentmond egymásnak. Hogy melyik a fontosabb, azt nem lehet első látásra megállapítani. Éppen ezért van szükség egy elmélet felállítására, amelynek alapjaként a többcél-függvényü optimalizálás törvényeit lehet alkalmazni.

\section{Az elméleti alap kidolgozása}

A bontófogat egyszerüsítve egy rúddal modellezhetjük. A rúd egyik vége befogott, a másik vége két koncentrált erővel terhelt.

Az egyik koncentrált erö (T) a rúd hossztengelyére merölegesen, a másik $(\mathrm{N})$ annak irányába hat.

Az $N$ erő a rúd minden keresztmetszetében hajlító nyomatékot, a $T$ erő pedig húzást-nyomást gyakorol. Tehát minden keresztmetszetben összetett igénybevétel keletkezik, ennek maximális értékét a következő egyenlettel lehet kifejezni:

$$
\sigma=\sigma_{N}+\sigma_{T}=\frac{N}{A}+\frac{M}{W}
$$

ahol

$\mathrm{N}$ - normál irányba ható erő;

$\mathrm{T}$ - merőleges irányba ható erő;

$\mathrm{M}$ - a T erő hajlítónyomatéka;

$\mathrm{x}$ - a keresztmetszet távolsága a bontófog éléig;

A - a keresztmetszet területe;

W- a keresztmetszeti tényező.

$\mathrm{Az}$ 1. és a 2. ábrákra alapozva, az $\mathrm{N}$ és T eröket a bontófogra ható $F x$ és $F y$ erök, illetve a mértani paraméterek függvényében a következő módon lehet meghatározni:

$$
\begin{aligned}
& N=F x \sin (\alpha+\delta / 2) \pm F y \cos (\alpha+\delta / 2) \\
& T=F y \sin (\alpha+\delta / 2) \pm F x \cos (\alpha+\delta / 2)
\end{aligned}
$$

Mivel az $F_{x}$ vágóerö és az $F_{y}$ rányomó erő között létezik a következő összefüggés:

$$
F_{y}=k_{y} \cdot F_{x},
$$

a (2) és (3) egyenleteket a következő alakban lehet átírni: 
$N=F x(\sin (\alpha+\delta / 2) \pm k y \cos (\alpha+\delta / 2))$

$T=F x(\cos (\alpha+\delta / 2) \pm k y \sin (\alpha+\delta / 2))$

Mind az Fx és Fy erők, mind a ky együttható szintén az $\alpha$ szög és a h fogásmélység függvényében változnak.

Az (1) egyenlet tehát a következőképen alakul:

$$
\sigma=\sigma_{N}+\sigma_{T}=\frac{N(\alpha, h)}{A(x)} \pm \frac{T(\alpha, h) \cdot x}{W(x)}
$$

Az optimalizálás feladata egyrészt az, hogy a keresztmetszet alakváltozása az egyenszilárdságú rúdhoz minél közelebb legyen, másrészt pedig, hogy a maximális feszültség ne haladja meg az anyag megengedett feszültségét.

Tehát:

$$
\begin{aligned}
& \sigma(x)=\text { const. }, 0<x<1_{o}, \\
& \sigma(x)<\sigma_{a}
\end{aligned}
$$

Mivelhogy a bontófog hosszirányában a keresztmetszet alakja változik, az A(x) és $\mathrm{W}(\mathrm{x})$ függvények leírásához a MATHCAD programot használtuk. A 6. ábrán, az analitikusan szerkesztett hosszmetszet, a 7. és $\mathbf{8}$. ábrákon pedig a keresztmetszet területe és a keresztmetszeti tényező változásának a görbéi láthatók.

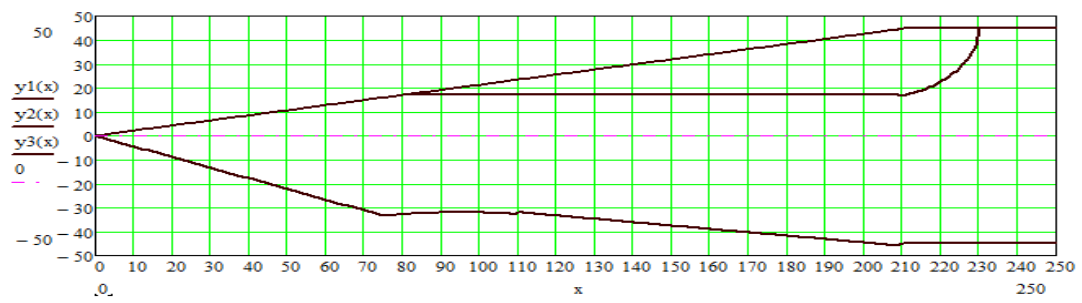

6. ábra. A bontófog analitikusan szerkesztett hosszmetszete

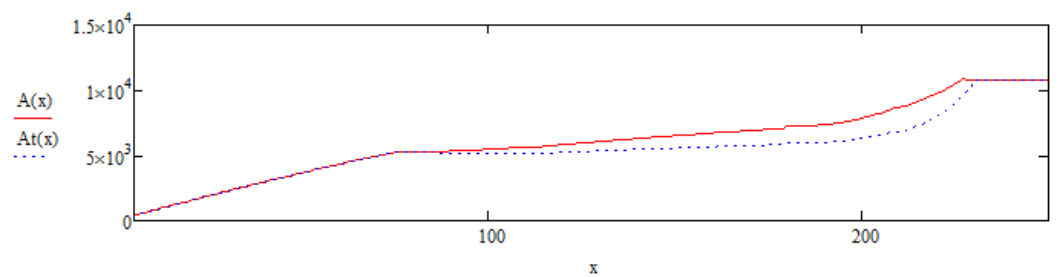

7. ábra. A bontófog keresztmetszete területének változása

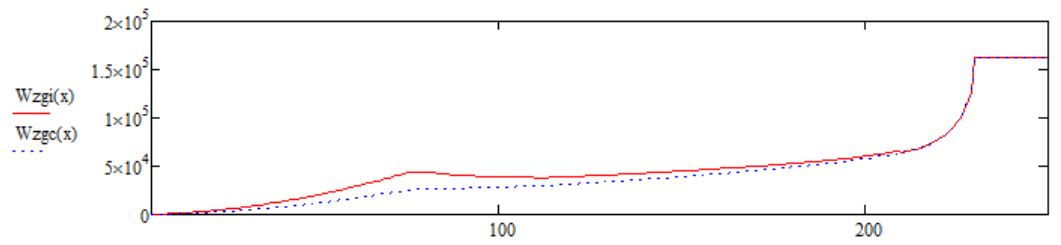

8. ábra. A bontófog keresztmetszeti tényezőinek változása 


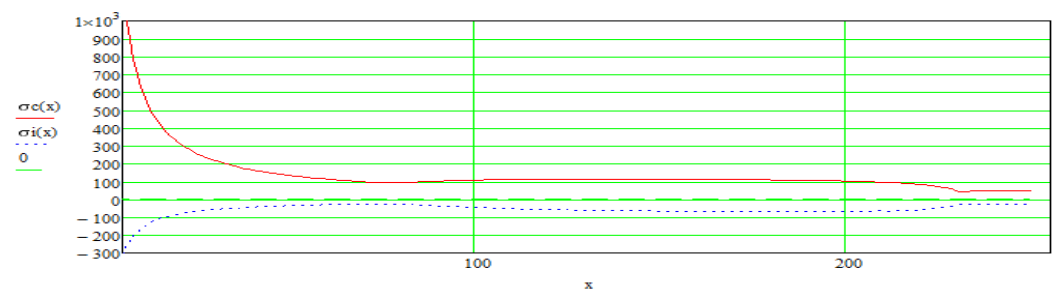

9. ábra. A bontófog keresztmetszetén keletkezö húzás nyomás feszültségek diagramjai

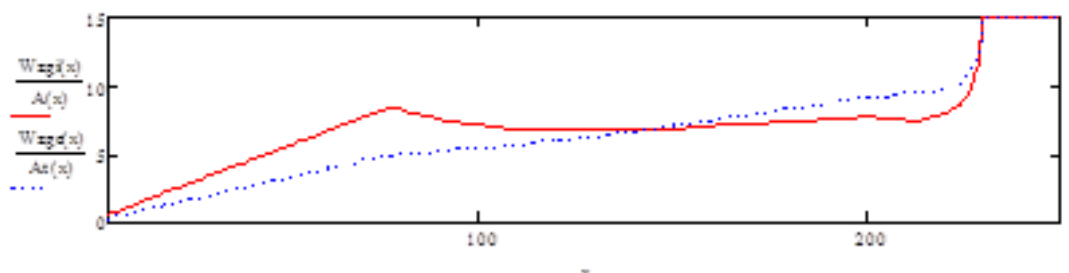

10. ábra. A bontófog keresztmetszetét jellemzö $W(x) / A(x)$ változása

A húzás-, illetve nyomásfeszültségek diagramjai a 9. ábrán láthatók. Az ábrákból kitünik, hogy a bontófog élétől mérve egy 40 milliméteres szakasz kivételével a feszültség majdnem állandó értékű, ami bizonyítja az optimalizálási kritérium helyességét.

A 10. ábrán, a $\mathrm{W}(\mathrm{x}) / \mathrm{A}(\mathrm{x})$ hányadosát ábrázoltuk.

Bonyolultabb számításokkal, amelyeket most nem részletezünk, bebizonyitható hogy egy, a keresztmetszet alakjában és méreteiben változó, egyik végén befogott rúd akkor egyenszilárdságú, ha a $\mathrm{W}(\mathrm{x}) / \mathrm{A}(\mathrm{x})$ hányados lineárisan növekszik a hossz függvényében.

Ebböl az ábrából az is következik, hogy ez a megállapítás igaz.

\section{Gyakorlati alkalmazások}

A külszíni bányákban jövesztett lignitféleségek és a különböző meddő kőzetek különbözö fogparamétereket igényelnek ahhoz, hogy a jövesztés minimális energiafogyasztással történjen.

A bontófoggyártás szempontjából, az lenne előnyös, ha minden esetben ugyanazt, tehát egy univerzális bontófogat alkalmaznánk. Ebből az következik, hogy az egyik szempontot sem lehet kivételesen követni, hanem megegyeztető megoldást kell alkalmazni.

Ez azt jelenti, hogy az adott helyzetben a különböző körülményeket úgy kell csoportosítani, hogy ezek a jövesztés szempontjából közel álljanak egymáshoz, s az így kapott csoporthoz a megfelelő paraméterekkel rendelkező bontófogat kell kifejleszteni.

Lényegében a bontófog formája ugyanaz, de a fontos paraméterek csoportonként mások, s így születik meg a bontófog több racionálisan választott változatban. Ezek megfelelő alkalmazása minden esetben jó eredményhez vezet, mind az energiafogyasztást, mind a bontófogak gyártását illetően.

A kidolgozott és bemutatott elméletet alkalmazva a dél-romániai lignitmedence 7 . vizsgált telepét és az itt jövesztendő meddőkőzeteket három csoportba osztottuk a fajlagos vágóerő szerint, s így nem három bontófog szükséges, hanem csak egy, ugya- 
nazon formájú három változatban, amint az 1. táblázatban látható.

A geometriai paraméterek meghatározásánál figyelembe vettük a meríték élére ültetett bontófogat és annak alapformáját, ami a három változatnál nem módosul.
Ugyanakkor figyelembe vettük a leghasználtabb merítékek adatait, és így jött létre a javasolt bontófog alapformája és annak főbb méretei, amelyek a 11. ábrán láthatók.

1. táblázat. A fajlagos vágóerő és az ajánlott bontófog változatai

\begin{tabular}{|c|c|c|c|c|}
\hline $\begin{array}{l}\text { Jövesztett anyag } \\
\text { Fajlagos } \\
\text { vágóerő } \\
\text { N/cm }\end{array}$ & Meddő kőzet & Lignittelepek & Külszíni bánya & $\begin{array}{l}\text { Bontófog- } \\
\text { változat }\end{array}$ \\
\hline \multirow[b]{2}{*}{$A=200 \ldots 450$} & Homokos agyag & - & Roşia de Jiu & \multirow[b]{2}{*}{ I } \\
\hline & Zöldes agyag & - & $\begin{array}{l}\text { Roşia de Jiu } \\
\text { Husnicioara } \\
\end{array}$ & \\
\hline \multirow{5}{*}{$A=450 \ldots 800$} & Homokos márga & - & $\begin{array}{l}\text { Berbeşti (Panga) } \\
\text { Oltețu }\end{array}$ & \multirow{5}{*}{ II } \\
\hline & Márgás agyag & V, VI, VII, VIII & Lupoaia & \\
\hline & Szürke agyag & VII, VIII & Roşiuţa & \\
\hline & - & $\mathrm{V}, \mathrm{VIII}$ & Roşia de Jiu & \\
\hline & - & I, IV & Husnicioara & \\
\hline \multirow{2}{*}{$A=800 \ldots 1200$} & - & I, II & Olteţu & \multirow{2}{*}{ III } \\
\hline & - & V, VII & Peşteana Nord & \\
\hline
\end{tabular}
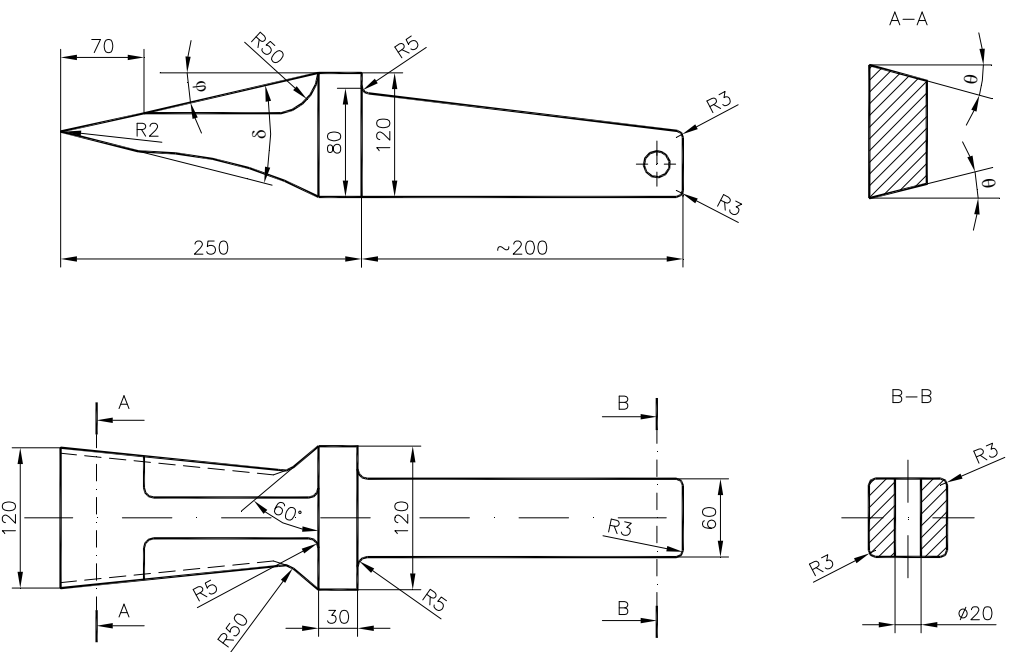

11. ábra A javasolt bontófog alapformája és adatai 
2. táblázat. A javasolt bontófog három változatának geometriai paraméterei

\begin{tabular}{|l|l|r|c|c|c|}
\hline \multirow{2}{*}{$\begin{array}{l}\text { Sor } \\
\text { sz. }\end{array}$} & \multirow{2}{*}{ Geometriai paraméterek } & \multirow{2}{*}{ Jelölés } & \multicolumn{3}{|c|}{ Bontófogváltozat } \\
\cline { 4 - 6 } & & & I-Meddö & $\begin{array}{l}\text { II-Meddö } \\
+ \text { lignit }\end{array}$ & III-Lignit \\
\hline 1. & Homlokszög & $\alpha$ & $55^{\circ}$ & $52^{\circ}$ & $47^{\circ}$ \\
\hline 2. & Hátszög & $\delta$ & $7^{\circ}$ & $7^{\circ}$ & $7^{\circ}$ \\
\hline 3. & Ékszög & $\gamma$ & $38^{\circ}$ & $31^{\circ}$ & $36^{\circ}$ \\
\hline 4. & Vágószög & $\xi$ & $5^{\circ}$ & $38^{\circ}$ & $43^{\circ}$ \\
\hline 5. & Hosszanti oldalszög & $\theta$ & $3^{\circ}$ & $3^{\circ}$ & $5^{\circ}$ \\
\hline 6. & Keresztirányú oldalszög & $\varphi$ & $13^{\circ}$ & $13^{\circ}$ & $3^{\circ}$ \\
\hline 7. & A hátfelület dőlésszögének átlagértéke & $\mathrm{b}$ & $120 \mathrm{~mm}$ & $120 \mathrm{~mm}$ & $120 \mathrm{~mm}$ \\
\hline 8. & A vágóél szélessége & &
\end{tabular}

A 2. táblázatban a három változat bontófog geometriai paraméterei figyelhetők meg, ahonnan kitünik, hogy mi marad állandó, és mi változik a fog homlokszöge értékéből kiindúlva. Látható, hogy ezek értéke sorban $55^{\circ}, 52^{\circ}$ és $47^{\circ}$, a megfelelő ékszögek értékei pedig rend $28^{\circ}, 31^{\circ}$ és $36^{\circ}$. Tehát az I.-es bontófog kisebb, a III.-as nagyobb szilárdsággal rendelkezik, a II.-es közepes.

Gyakorlatilag az alapformát és a meghatározott paramétereket figyelembe véve megterveztük a három fogváltozatot, amelyek a 12., 13. és 14. ábrákon láthatók. Itt a elöállításhoz szükséges összes mértani adat fel van tüntetve.

Amint látható, felülnézetben a bontófog szimmetrikus, míg oldalnézetben kissé aszimmetrikus.
A homlokfelület sík és folytonos a megengedett kopáshatárig, a másik oldal nem folytonos, és a $7^{\circ}$-os hátszög biztosítja a fölösleges és energianyelö súrlódás kiküszöbölését, akárcsak az oldallapok esetében.

Ami a nyél adatait illeti, azok viszonylagosak, mert a merítéken található fogtartók formájától és a geometriai méreteitől függnek

A három javasolt bontófogváltozat fó méretei ugyanazok, az élszögek viszont különböznek, kivéve a hátszöget és az oldalszögeket.

Ami a konstrukció alapanyagát illeti, azt úgy kell megválasztani, hogy minél nagyobb fajlagos teherbírása és jó kopásellenes tulajdonságai legyenek.

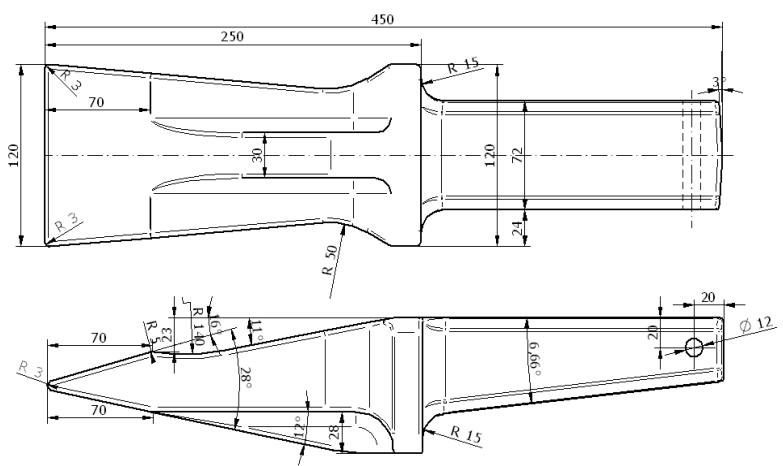

12. ábra $A$ javasolt bontófog I. változata 


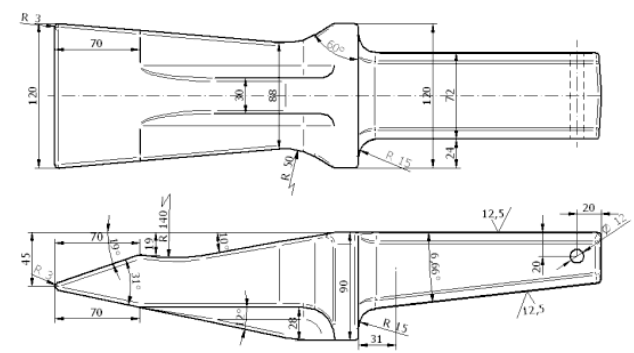

13. ábra. A javasolt bontófog II. változata

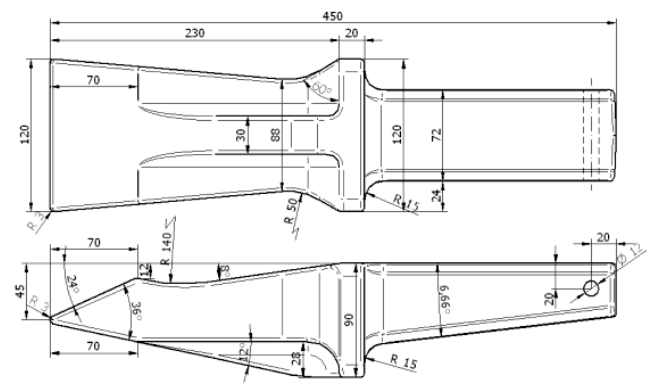

14. ábra. A javasolt bontófog III. változata

\section{Következtetések}

Az elöbbiekben bemutatott eredmények alapján a következő következéseket vonhatjuk le:

- a marótárcsás kotrógépek esetében a bontófogak mértani paraméterei lényegesen befolyásolják a jövesztést és a gép müködését, főleg ami a marótárcsát, a merítékeket és a bontófogakat illeti, mind technológiai, mind energetikai szempontból;

- az optimalizálás legfontosabb lépése a bontófogakra mint önálló elemekre vonatkozik;

- az önálló bontófog geometriai paraméterei és a merítékre szerelt bontófog geometriája között pontos összefüggések vannak, amelyek szigorú betartása kötelező a jövesztett kőzet és a marótárcsa között létrejövő kölcsönhatás és a kotrógép megfelelő müködése szempontjából;
- a jövesztési folyamat egy komplex jelenség, amely egy többcél-függvényü optimalizálási megközelítést igényel;

- a valóság megközelítésének céljából, a kifejlesztett elméletben található matematikai összefüggésekbe a gyakorlatból vett mérések alapján meghatározott adatokat használunk fel;

- a bontófog alapformáját és az elemzés alapján meghatározott paramétereket figyelembe véve három bontófog-változatot terveztünk meg, amelyek a gyakorlatban felhasználhatók.

\section{Szakirodalmi hivatkozások}

[1] Kovács I., Ilias N., Nan M.S.: Regimul de lucru al combinelor miniere. Editura UNIVERSITAS, Petroşani, 2000.

[2] Nan M.S.: Parametrii procesului de excavare la excavatoarele cu rotor. Editura UNIVERSITAS Petroşani, 2007.

[3] Sümegi I.: Külfejtési marótárcsás kotrógépek jövesztö szerkezetének elméleti vizsgálata és fejlesztése. Doktori értekezés $\mathrm{PhD}$ elnyeréséhez, Miskolci Egyetem. 